\title{
Write On, Women! Discovering Personal Skills through Feminist Pedagogy and Narratives
}

\author{
¡Sigan escribiendo, Mujeres! Las habilidades personales por \\ medio de la pedagogía feminista y las narrativas
}

\author{
Ana Olga Rallón ${ }^{1}$ \\ Anna Carolina Peñaloza-Rallón ${ }^{2}$
}

\begin{abstract}
In this pedagogical proposal, we utilized Feminist Pedagogy and narratives to reveal women's skills that they had silenced in their cover letters for employment. Five females' narratives were analyzed using aspects of the grounded theory method to answer the question: What do women's narratives reveal about their personal skills otherwise silenced in their cover letters? The results showed that women find strength in their spirituality, as well as demonstrating loyalty, flexibility, respectfulness, and resilience. All of the women wrote about their decision-making abilities, which included organization, responsibility, and problem-solving. Finally, the stories revealed that women's ability to make choices defined their freedom and their future.
\end{abstract}

Keywords: academic writing, feminist pedagogy, narratives, silence, skills, voice, workforce

She holds a BA in Education with an emphasis on English from the University of Arizona and a course of specialization in Liberal Arts. She currently teaches undergraduates at the Universidad Pedagógica y Tecnológica de Colombia. She has initiated several outreach programs and works to help vulnerable communities. ana.rallon@uptc.edu.co

ORCID ID: https://orcid.org/0000-0002-9508-4926

2 She holds a master's in Language Teaching from Universidad Pedagógica y Tecnológica de Colombia and a BS in Environmental Science from the University of Arizona. She teaches second language acquisitioning, research, teaching methods, and academic writing. Additionally, Anna is a member of the research group TONGUE. She is an advocate of critical pedagogies and social equity in the community. anna.penaloza@uptc.edu.co

ORCID ID: https://orcid.org/0000-0002-6394-4346

Received: April 12th, 2020. Accepted: November 18th, 2020.

This article is licensed under a Creative Commons Attribution-Non-Commercial-No-Derivatives 4.0 International License. License Deed can be consulted at https://creativecommons.org/licenses/by-nc-nd/4.0. 
Ana Olga Rallón,

Anna Carolina Peñaloza-Rallón

\section{Resumen}

En esta propuesta pedagógica, implementamos la pedagogía feminista y las narrativas como opción para revelar las habilidades silenciadas por las participantes en sus cartas de presentación. Analizamos las narrativas de cinco mujeres utilizando aspectos de la teoría fundamentada para responder a la pregunta: ¿Qué revela las narrativas de las mujeres acerca de sus habilidades personales silenciadas en las cartas de presentación? Los resultados muestran que las mujeres encuentran fortaleza en su espiritualidad, además de su lealtad, flexibilidad, respeto y resiliencia. Todas las participantes narraron su habilidad de tomar decisiones y ser organizadas, responsables y resolver problemas. Las historias revelaron que la habilidad de tomar decisiones se conecta con la libertad y el futuro de las mujeres.

Palabras claves: escritura académica, fuerza laboral, habilidades, narrativas, pedagogía feminista, silencio, vOz

\section{Introduction}

Gender inequality is a reality that exists everywhere, and it has been widely documented in all aspects of education, family life, and the workplace (Badura, Grijalva, Newman, Yan, \& Jeon, 2018; Castañeda-Peña, 2010; de Beauvoir, 1949; de Pádua Carrieri, Diniz, de Souza, \& Menezes, 2013; Eagly \& Karau, 1991; Fine \& Shen, 2018; and the World Health Organization, 2018). In Colombia, the gender gap is alive in academia, government, and the employment sector with examples from lower wages to fewer high-ranking positions occupied by women (Miniciencias, 2018; El Tiempo, 2018; Franco-Orozco \& Franco-Orozco, 2018; UNESCO, 2016). Despite the push to include more women in higher positions, we continue to see fewer female researchers, governmental representatives, and CEOs.

Two major factors accounting for the inability to close the gap are prescribed social gender roles and gender stereotypes. Social gender roles encompass the behaviors, attitudes, beliefs, etc., of being a woman or a man, which have been determined by society. These roles are socialized at a young age through toys, color of clothing, and activities enforced by parents, peers, and teachers. As children become adolescents, they continue to perpetuate these behaviors (Pavlova \& Silbereisen, 2015). In college, being a man or a woman will also affect the way a person positions him or herself as leaders, risk-takers, supporters, and emotional beings (Peñaloza, 2019). Therefore, the university becomes a crucial arena to

164 combat the negative effects of social gender roles and gender stereotypes in the workplace. Since gender is socially co-constructed with others in interaction (Butler, 1990; Coates, 1998), reevaluating the way everyday college spaces can be used to promote gender equity before college students enter the workforce is a necessity.

At the Colombian public university where we teach, the administration has taken measures to ensure a more inclusive university. In January 2019, the university created its first gender and human rights committee. Additionally, the administration passed a mandate 
last year that all undergraduate diplomas need to include the male and female version of the noun in Spanish. Given that Spanish is the native language, both the male and female titles exist for any major, e.g., biólogo (male biologist) and bióloga (female biologist). Up until now, only the male gendered noun had been used for all diplomas regardless of sex. The new mandate assured that men and women would receive their undergraduate diploma with their respective male or female noun, such as Licenciado or Licenciada ${ }^{3}$. In addition, several studentrun groups, as ACEU (Asociación Colombiana de Estudiantes Colombianos), are avid promoters of gender inclusive activities, rallies, and talk circles. Nevertheless, one space remains untouched by the administration and is largely reliant on teacher autonomy: the classroom.-

The English academic writing classroom can fall victim to traditional, colonized teaching practices. In the traditional classroom, the teacher is the focus and provider of all knowledge. Meanwhile, the student receives this knowledge and reproduces it by memory, usually during an exam (Anzoátegui, 2016). Because of the hierarchies within the traditional classroom, we argue that traditional teaching methods continue to cycle notions of hegemony and patriarchy that perpetuate social gender roles and stereotypes. Additionally, academic writing in English is a system of language structures and rules that favor Standard English and native speakerism (Mauranen, Pérez-Llantada, \& Swales, 2010). From experience, there is little room to question these structures or negotiate the language itself. Language learners can feel frustrated and alienated from the act of writing in English. Nevertheless, the academic writing classroom is a pivotal space for both men and women in terms of professional development. Upon graduation, students will be asked to write cover letters, elaborate résumés, report on research studies, develop personal statements, take international English proficiency exams, and prepare for interviews in a foreign language for studies abroad and even national job opportunities. Therefore, the academic writing classroom becomes a transformative place to help men and women gain confidence in their writing and themselves.

For this pedagogical proposal, we worked with five female participants in an academic writing class focused on developing professional documents like cover letters, résumés, articles, and personal statements. At the beginning of the cover letter unit, we noticed that the female participants had difficulty writing about their professional skills. Cover letters are particularly essential because they highlight the candidate's educational background, work experience, and personal skills. In addition, cover letters accompany résumés and job applications for future employment and scholarship opportunities. According to the Purdue Online Writing Lab (n.d.), the cover letter "is the first document an employer sees, so it is often the first impression you will make" (para. 1).

Although the female participants wrote about their educational backgrounds, they failed to expand on their personal skills. Personal skills, such as leadership, flexibility, persistence,

Title given to individuals holding an undergraduate teaching degree in Colombia. 
Ana Olga Rallón,

Anna Carolina Peñaloza-Rallón

and successful teamwork, are all factors that can influence being hired and promoted. In interviews with the women, the main reason for leaving out their personal skills was that they did not feel they had them, or they preferred to repress them over more preferable social gender roles like being supportive. In an interview with Cami, one of the participants, she mentioned that writing about one's self was difficult:

Al momento de responder las habilidades, si fue un poco difícil porque es dificil responder al yo, sobre uno mismo, es difícil lo que uno es y lo que uno bace y saber en qué uno es bueno es difícil reconocerlo a vecest.

Given that our intervention ${ }^{5}$ had failed to make an impact on the participants' writing choices about their personal skills, we decided to look for an alternative solution.

Narratives are often used in the language classroom to promote storytelling, sharing, and connection to ourselves and others. In addition to using narratives, we also considered turning to Feminist Pedagogy, which is a way to look at education and the classroom "as a liberatory environment in which we, teacher-student and student-teacher, act as subjects, not objects" (Shrewsbury, 1987, p. 6). In the feminist classroom, narratives can emphasize knowledge from the narrator's experience and point of view (Webb, Allen, \& Walker, 2002). All in all, feminist pedagogy and narratives could engage the participants in their own writing experiences and help them recognize their own skills without the limiting structures of the cover letter.

Therefore, we focused our pedagogical proposal on implementing narrative writing coupled with the pillars of Feminist Pedagogy. We asked the women to write a story based on the prompt: "Tell us about a moment that impacted your life". For this article, we analyzed the five participants' stories guided by the research question: What do women's narratives reveal about their personal skills otherwise silenced in their cover letters? The narratives revealed skills like strength in spirituality and decision-making, which the women failed to mention in their cover letters.

\section{Our Experiences as the First Source of Knowledge}

Feminist theory "privileges personal lived experiences as the basis for analysis, theory generation, activism, and research” (Foss \& Foss, 1994, as cited in Web, Allen, \& Walker,

When writing about skills, talking about ourselves was difficult. Stating what one is and what one can do is difficult, as well as knowing what one is good at. What we are good at can sometimes be difficult to recognize.

This intervention consisted of four sequential lessons ( 2 hours each) about cover letters. Activities such as brainstorming personal skills, writing strengths and weaknesses, and reading other cover letters were part of the intervention. Additionally, we sat down with each participant for a private tutoring session in order to discuss the rough drafts and final cover letter. The intervention took place before implementing the narratives.

HOW Journal 
2002). Therefore, we begin the discussion by introducing our experiences and positions in regard to writing, teaching, and being women.

We are a mother and daughter researching, writing, teaching, and living together. As the mother, I moved to the United States in the 1980s. Though I had studied in a prestigious language institute in Colombia, I was overwhelmed when I moved to the USA. I wanted to escape because I did not understand anything. My only form of communication was through writing, but I could only write simple sentences. Later, I enrolled in the university. I took ESL courses along with my major core classes. I struggled with writing every college essay, but I felt so blessed that one of my advisors, Dr. Johnson, reviewed my papers. He encouraged me to keep fighting and never give up. Things got easier for me, which helped me have access to a better quality of life.

As the daughter, I grew up in the United States. I studied a career in STEM (Science, Technology, Engineering, and Mathematics). Growing up, I was usually the best writer in class, and I loved to write essays and poems alike. College was a difficult place for me because it was the first time, I was not good at writing. I would try to express myself with elaborate, thought-provoking introductions to my science papers. I remember that a teacher once wrote on my essay "This is Science, not science-fiction". Due to the previous and the fact that I did not see myself represented in my field, I internalized the belief that I could never be a researcher. To this day, I struggle with writing and the evaluation process. Nevertheless, I fight for what I believe could be a change in academic writing.

From our experiences, we position ourselves as women who both have struggled with academic writing in different ways. We believe that other women have undergone feelings of stress, insecurity, and alienation from writing in their native or second language. We also recognize that who we are has shaped us as educators. Therefore, we value the role that positive and constructive feedback has on students' writing. Moreover, we were in favor of searching for alternative methods to empower our students as writers. We turned to feminist pedagogy to find a solution in our classroom.

\section{Feminist Pedagogy: A Brief History}

Feminist pedagogy is linked to feminist theory, which seeks to question traditional ways of being and thinking that continue to perpetuate patriarchal ideologies (Tong, 2001). Feminist pedagogy strives to break down positions of power and oppression that affect women and men in all aspects of life. According to Shrewsbury (1987), feminist pedagogy "is a theory about the teaching/learning process that guides our choice of classroom practices by providing criteria to evaluate specific educational strategies and techniques in terms of desired course goals and outcomes" (p. 6). Feminist pedagogy started in the field of women's studies, but it has expanded to other disciplines as a way to counteract traditional 
Ana Olga Rallón,

Anna Carolina Peñaloza-Rallón

methodologies (Shackelford, 1992), such as bell hooks' application of Freire's work on critical pedagogy and her own experiences in education to give birth to a new methodology of teaching and learning (Bauer, 2000). Because of its origins, feminist pedagogy is often linked with critical thinking and literacy to question, analyze, evaluate, reflect, and transform society.

On the origins of feminist pedagogy, bell hooks ${ }^{6}$ contributed greatly to the inclusion of poor and marginalized groups. In fact, much of the work done to raise feminist awareness was printed, and bell hooks argued that many poor, black men and women could not read or write (Bauer, 2000, p. 266). Consequently, much of her work is based on reaching out to the community and creating small-scale programs to teach reading, writing, and critical thinking skills. All in all, bell hooks claims that feminism should go hand in hand with practicality in order to make a difference.

bell hooks has also provided significant input in terms of feminist pedagogy. Based on her educational experiences, she established that the classroom needed to be a space to question traditional and oppressive behaviors. According to her, the feminist classroom is "where we work together as teachers and students to overcome the estrangement and alienation that have become so much the norm in the contemporary university" (hooks, 1989, p. 51). Additionally, hooks highlighted that the learning process needs to be real and human.

Another major milestone in feminist pedagogy was the idea that the teacher was not the source of all knowledge and power. Rather, the teacher could use his or her power to "enrich and it is this choice that should distinguish feminist pedagogy from ways of teaching that reinforce domination" (hooks, 1989, p. 52). Furthermore, knowledge was to be co-constructed in the classroom with special attention to personal experience. Since hooks' first contributions to the field, many other scholars have added to the experience, thereby, defining the pillars that make it different from other types of pedagogy.

\section{Privileging the Individual Voice as a Way of Knowing}

Webb, Allen, and Walker (2002) identified six pillars of feminist pedagogy, which are: (1) Reformation of the relationship between teacher and student, (2) empowerment, (3) building community, (4) privileging the individual voice as a way of knowing, (5) respect for diversity of personal experience, and (6) challenging traditional views. These six pillars highlight the need to promote symmetrical power relationships between teacher and students,

bell hooks is the pseudonym of the author, activist, and professor Gloria Watkins. Watkins published her first book, Ain't I a Woman: Black Women and Feminism, under her pseudonym (bell hooks), which was her great-grandmother's name. The reason for writing her pseudonym in lowercase letters was a decision made by Watkins as a way to allocate the focus on her work and message rather than herself (The Editors of Encyclopaedia Britannica, 2020). 
understand hegemonic structures in society, foster collaborative and transformative work, listen to students' opinions and interests, decolonize ways of being, and question dominant structures. We considered all of the six pillars in making a transformation in the classroom. For this study, we focused on the fourth pillar, as it led us to consider narratives as the means to listen to our students' voices and challenge the cover letter structure.

The concept of 'voice' is often talked about in transformative educational practices. The student's voice refers to his or her opinions, interests, and feedback. Unfortunately, this voice can be silent and/or silenced depending on the context and power relationships in place. The idea of 'privileging the individual voice' comes from acknowledging our students' voices and our own as sources of valid knowledge.

One recommendation is to make the students' voice an integral part of every class. As Webb, Allen, and Walker (2002) stated, "Voice need not be reserved for oral performance courses; rather, the unique voice of each student in any classroom affords a path to knowledge and a methodology for each student in any classroom" (p. 70). bell hooks (1989) mentioned that she would have her students read paragraphs out loud in class just so that she could hear their voices. In that sense, she could also get a feel for how they interacted with the material in order to provide them with individual help.

\section{Narratives}

One way to amplify voice is through the personal narrative. The feminist classroom is "an important place to connect to our roots, our past, and to envision our future" (Shrewsbury, 1987 , p. 6). Narratives and oral story telling can be used as means of expressing our past, present, and future according to the way the narrator interprets his or her experiences. According to Langellier (2001), "people make sense of experience, claim identities, and 'get a life' by telling and writing their stories" (p. 700). In addition, narratives allow all of the previous to be created from a personal standpoint. According to Rappaport (1995), "For many people, particularly those who lack social, political, or economic power, the community, neighborhood, or cultural narratives that are available are either negative, narrow, 'written' by others for them, or all of the above" (p. 796). Because of this, narratives are essential in feminist research since they allow the female narrator to claim her story without the constraints of hegemonic structures.

Voice and Silence. Given that the narrative is told from the author's perspective, it is a door to understanding voice and silence. Voice is a concept that refers to students' opinions, beliefs, perceptions, and more. Voice has been a topic reviewed extensively in Colombia and in English as a Foreign Language, such as in materials development (Ramos \& Aguirre, 2014), in exploring pre-service teachers' intercultural communicative competence (Olaya \& Gómez, 2013), and journal writing (Castellanos, 2008), to name a few. In all of these studies, 
Ana Olga Rallón,

Anna Carolina Peñaloza-Rallón

the main concern is in making sure that students' voices are represented and heard in the classroom. In our experiences as educators, we believe that the problem is not about giving students a voice, as they already have one, but rather learning to listen to those voices. Learning to listen to students' voices counteracts a history of silenced voices in the traditional classroom.

Silence can have both positive and negative connotations in terms of writing. Teleky (2001) pointed out that:

In its more positive associations, silence is linked to ecstasy, bliss, communion, rest, sympathy, identification, reflection, meditation - $\mathrm{n}$ both Eastern and Western religions-as well as secrets. The more negative associations of silence include denial, concealment, evasion, punishment, rejection, depression, burden, threat, doubt, conspiracy, and, again, secrets. (p. 207)

We wanted to bring up the positive aspects of silence because silence is not a 'bad' thing. In fact, students should be able to remain silent if that is their choice. The issue comes from a person silencing his or her voice or being silenced by others, thereby, causing the negative aspects of silence. In regard to this study, we noticed that the female participants had issues writing their skills. In an informal conversation, the students expressed that they did not have anything to contribute to an employer. In other cases, they fell back on female social gender roles like caring for others and being a good team worker despite being leaders in the classroom (Peñaloza, 2019). By integrating narratives, coupled with an overall transformation of the classroom, our goal was to reveal personal skills that the women themselves had silenced in their cover letters because of their insecurities.

\section{Pedagogical Proposal}

\section{The Course}

We created the Academic Writing in English course in 2017 as a way to help medical students develop cover letters, résumés, and articles for publication in English. In the second semester of 2018, the course was launched by the university language institute for all other undergraduate students in the community. To this day, the course lasts one semester and

170 includes subjects related to the social, psychological, and cultural aspects of writing. The units covered in the course are: Persuasive Writing, Cover Letters, Résumés, and Job Employment, as well as Technical Writing. An additional unit on narratives was included as a result of this study.

\section{The Participants}

The course was initially piloted with 12 female participants, of which 10 were undergraduate students and two were English language teachers. In order to look at the 
narratives in detail, we analyzed five of the participants' stories ${ }^{7}$. All of the participants signed a consent form before starting the study.

\begin{tabular}{|l|l|}
\hline \multicolumn{1}{|c|}{ Pseudonym } & \multicolumn{1}{c|}{ Major/Occupation } \\
\hline Mik & English language teacher \\
\hline CM Barbosa & English language teacher \\
\hline Cami & Modern Languages \\
\hline Johanna & Modern Languages \\
\hline Srta. Conni & Biology \\
\hline
\end{tabular}

\section{Background}

The need to find an alternative to our academic writing classroom came from the unit Cover Letters, Résumés, and Job Employment. The students had to fill out a cover letter rough draft worksheet. After receiving teacher and peer feedback, they would write the final draft. Initially, the students had issues expanding on their skills, for which we wrote over 50 different skills on the board. Even so, they wrote less about their skills and achievements in comparison to other sections like educational background and work experience. The following excerpts come from the students' cover letters:

I am the best candidate because I have the English level and education to be a translator. I have the communicative skills and I consider myself as a multitasker, so I learn quickly. [sic] (Johana, Cover letter)

I am punctual, I have a positive attitude and I am a social person. [sic] (Cami, Cover letter)

In an interview, Johana mentioned that writing the cover letter was difficult for her. She stated that, "Sí me parece complicado, es como de que yo que se hacer" [sic] (Johanna, Interview).

Based on the students' comments, we noticed that writing about their accomplishments and skills was difficult for the female students. This did not happen because of their lack of vocabulary or language proficiency level in English, but rather they felt they had little to contribute to a potential employer. Furthermore, the cover letter format was awkward and unfamiliar to them.

We selected these five narratives based on language level, consent, and availability. All five participants signed the consent form, had at least a B1 level of English, and were willing to engage in follow-up interviews in relation to the study.

8 Yes, I think it (writing the cover letter) is complicated. It's like, what do I know how to do? 
Ana Olga Rallón,

Anna Carolina Peñaloza-Rallón

\section{Objective of the Pedagogical Proposal}

The main objective of this proposal was to introduce narrative writing to complement students' cover letters. The final product of the unit was a true account narrative based on the prompt: Tell us about an event that impacted you as a person. We analyzed the students' final narratives for this proposal guided by the question: What do women's narratives reveal about their personal skills otherwise silenced in their cover letters?

\section{Implementation of the Proposal}

The proposal took five weeks to be implemented. Given that feminist pedagogy encompasses everything from the classroom to the roles of the teacher and student, we enforced or added aspects of the six pillars of feminist pedagogy (Webb, Allen, \& Walker, 2002) for the remainder of the course. The organization of the classroom and the roles of the teacher and students are explained below.

I. Reformation of the relationship between teacher and student: We arranged the desks in a circle during each meeting, which helped with equal sharing opportunities. We no longer occupied the front of the room, as we were integrated with the group.

II. Empowerment: The students could choose to share what they wanted with the group. They had a democratic space to voice their opinions and give feedback without judgement.

III. Building community: When tasks were assigned, we always encouraged collaborative work. Since the participants came from different backgrounds, they got to know and understand each other.

IV. Privileging the individual voice as a way of knowing: Each student's experience, knowledge, and voice was valued and respected. Before starting the lesson, the students wrote about the topic in journals and discussed their entries out loud.

V. Respect for diversity of personal experience: We encouraged the idea that there was no perfect way of being or seeing the world.

VI. Challenging traditional views: By asking the students to write a narrative and share their experiences, we challenged the notion of what academic writing was. Additionally, the narrative was an alternative way to display one's skills, strengths, struggles, weaknesses, etc. that deviated from the structured cover letter.

The above pillars demonstrate the positions that we took and the ways we changed the classroom to encompass feminist pedagogy as a whole. We point out that there are many 
ways to pursue feminist pedagogy (McClusker, 2017), and this is just one interpretation of it. As Ropers-Huilman (1999) pointed out, "Still, feminist teaching is not a 'pure' practice. It is affected not only by participants, but also by the institutions in place" (p. 119). By changing aspects of our classroom and understanding our positions, we believe that the students were able to feel more at ease. Therefore, the students' honesty and trust in their narratives comprised the result of an overall change in the classroom.

\section{Findings}

In the section that follows, we show the analysis of the narratives by adopting elements of the grounded theory method (Glaser \& Strauss, 1967). Feminist research and the grounded theory method (GTM) have gone hand in hand since the 1990s due to GTM's compatibility with qualitative inquiry and other fields (Plummer \& Young, 2010). According to Plummer and Young (2010), "when combined, it loosens the androcentric mooring of the empirical processes underpinning grounded theory, enabling the researchers to design inquiry with greater potential to reveal issues particular to the lives and experience of marginalized women" (p. 305). In other words, GTM and feminist inquiry can be used together to find information from the data themselves, as opposed to the theory first.

We followed the steps of open, selective, and theoretical coding of GTM (Glaser \& Strauss, 1967). We began by color coding each line in the narratives and giving it a name (code). Then, we looked at the data to look for patterns among the narratives. Finally, we developed the categories based on the data and research question. Four categories emerged from the data, but for purposes of this paper, we will have space to explore only two. In addition to presenting the categories, we included other additional personal skills that appeared in relation to the main categories.

\begin{tabular}{|c|l|l|}
\hline \multicolumn{1}{|c|}{ Research Question } & \multicolumn{1}{|c|}{ Categories } & \multicolumn{1}{c|}{ Additional Personal Skills } \\
\hline What do women's narratives reveal \\
$\begin{array}{l}\text { about their personal skills otherwise } \\
\text { silenced in their cover letters? }\end{array}$ & Spirituality as a Strength & $\begin{array}{l}\text { Loyalty, Flexibility, } \\
\text { Respectfulness, and Resilience }\end{array}$ \\
\cline { 2 - 3 } & Decision-making & $\begin{array}{l}\text { Organization, Problem- } \\
\text { solving, and Responsibility }\end{array}$ \\
\hline
\end{tabular}

\section{Spirituality as a Strength}

This category gets its name from a common theme in the English language teachers' narratives. CM Barbosa and Mik both wrote about a spiritual experience that had impacted their lives. From their stories, we noticed characteristics like loyalty to their faith, flexibility and openness to new ideas, the ability to question their own beliefs and others', and even 
Ana Olga Rallón,

Anna Carolina Peñaloza-Rallón

resilience to stay alive despite internal pain. Because spirituality is an uncommon topic to write about in cover letters or résumés, it can be considered as a silenced voice due to the textual genre. Spirituality and faith are often omitted from cover letters in order to avoid discrimination or religious oppression. However, we would like to point out that through these narratives we see aspects of the human being that are silenced in academic settings, the workplace, and certain textual genres. As Osborn (2007) mentioned, "the most significant damage done by positivism to the language teaching and learning enterprise may lie in its failure to understand the complexity of humanness" (p. 4). Furthermore, the author stated that spirituality or faith are seen as taboos in the language learning classroom, and "we, as critical scholars, have failed collectively to provide ample opportunity for the voices of those who see spirit and language as interrelated to be heard" (p. 5). If we are to listen to our students' voices, it seems pertinent to provide a space for them to express all of who they are. In doing so, our participants chose to write about their spirituality, which ended up highlighting their other strengths like resilience, loyalty, respectfulness, and more. Although these personal skills never appeared in their cover letters, their spirituality and faith certainly made these women strong, as was evident in their narratives. In the excerpt below, CM Barbosa began her narrative by introducing the mental state she was in,

I woke up that day feeling very sick. A type of feeling that made my whole body hurt, even my heart. My sickness was psychological; I was suffering from depression. [sic] (CM Barbosa)

From her introduction, we noticed how her depression took hold of every part of her body, mind, and soul. Often, these life-altering aspects are silenced in job interviews because they are considered subjective and emotional. Later on, in her narrative, CM Barbosa retold her attempt to commit suicide. However, she stated that,

Unexpectedly, I heard a voice inside of me say, "Don't do it, think of your girls." I was in shock. [sic] (CM Barbosa)

In her narrative, the voice she heard was later explained as that of God's. Because of her spirituality, CM Barbosa looked to her faith and God as a solution to her problem. She mentioned that,

All I wanted to do was cry. I cried all the way to the secret place, and I remember that I kept reciting a prayer that a very good friend taught me. This special prayer was like a balm to my desolated soul. [sic] (CM Barbosa)

From this excerpt, we could see a woman who had suffered tremendously. From her narrative, we got to see how much of this pain was lived in solitude and embarrassment. Because she could not speak of her condition to her family or students, she turned to God and prayer as the solution. As her story progressed, she mentioned how God had spoken to her and "filled the desert of my heart with sweet consoling words" (CM Barbosa). In God, 
she found comfort, assurance, peace, safety, and friendship. She concluded her narrative stating that:

Today, I am a determined woman, with joy in my heart, full of desire to live and please God, my daughters, and my family. The depression couldn't take me away from this world without experiencing the opportunity to get to know God and discover the real meaning of our existence on Earth. [sic] (CM Barbosa)

Due to her spirituality and loyalty to God, CM Barbosa was able to fight the battle of depression. God became her friend in her time of need. We also see how she positioned herself as a "determined" and happy woman, which is much different from the way she described herself at the beginning of the narrative. Additionally, we see in the narrator a sense of resilience against death itself. Her determination, resilience, and courage are aspects of herself that she failed to mention in her cover letter as personal skills. Through her story, we witness a strong woman who had survived death itself through her faith.

Mik, an English language teacher, also chose to write about her spirituality and God in her life. It is important to note that Mik and CM Barbosa are recent friends in real life. They took the course together and were role models for the other students in the class. The friend that Mik talked about in her story refers to CM Barbosa. Mik began her narrative by stating her previous beliefs about her faith. She mentioned,

I can say that before this experience, I was aware that He used to listen to my prayers. However, the possibility that He could talk to me directly, give me advice and / or good news was completely out of my human judgement. [sic] (Mik)

Mik began her narrative by stating where she stood as a believer while setting the stage as to how she would change her initial beliefs. In the next paragraph of her story, she stated how her friend introduced her to a new church. She mentioned that,

Although I am a Catholic practitioner, I accepted to go since I felt curiosity to go see how Christians (Protestants) [sic] worshipped God. Anyway, it was the same God and they followed the same doctrine [sic] (Mik).

From this excerpt, we can see a characteristic about Mik related to being flexible and respectful as regards others. She is flexible in the sense that she was willing to accept her friend's invitation despite her original beliefs. Additionally, we noticed that she is respectful of her friend's beliefs. In the last sentence, Mik showed her ability to find commonalities between her and her friend's faith, rather than judging her. After accepting her friend's invitation, she discovered that God could speak to her. Mik opened up about her fears and expressed them to her friend. She wrote, "I confessed my fear to her." Despite being afraid, Mik chose to hear God's word. Her reaction was as follows, 
Ana Olga Rallón,

Anna Carolina Peñaloza-Rallón

Consequently, this has been the strangest but most wonderful, beautiful, and amazing religious experience I had ever had. [sic] (Mik)

Similar to CM Barbosa, Mik found comfort in God. She discovered her newfound spiritual experience to be a source of amazement and shock. She concluded her story by reflecting on how God could change the world. Her final sentence stated, "Wow! Nobody could imagine how I felt!" Based on Mik's experience, we were able to see her sense of enthusiasm, curiosity, reflection, flexibility, and even ability to try new things. The narrative contrasted her cover letter, in which she primarily supported her accomplishments through her educational background and experience. Furthermore, she specifically failed to mention any personal skills. As she stated in her final cover letter:

Consequently, given my fifteen-year teaching experience, permanent training, education in English, and appropriate skills, I consider that I am the English teacher you are looking for. My professional data is as follows. [sic] (Mik, Cover letter)

In this category, we saw a number of personal skills that were not mentioned in the women's cover letters. In part, this is because the cover letter format favors a structured, organized display of certain accomplishments. Nevertheless, we can argue that no room is left for the exploration of emotionality or spirituality as a strength, as well as the strengths they highlight in a person's life. From the narratives, we realized a much different story. We got to see a side of CM Barbosa that had battled through depression and a suicide attempt, and she turned to her faith to find a solution. Even sharing the story, itself, is an act of courage and honesty, which are honorable personal skills to have in any employee. Meanwhile, Mik demonstrated her ability to respect and cooperate with others. She was able to find commonalities between her beliefs and that of her friend; this could be compared to aspects of interculturality. The narratives showed a more complete picture of the women that was invisible in reading their cover letters.

We conclude this category by mentioning that although spirituality and faith are seen as taboos in academic settings or in certain textual genres like the cover letter, these experiences help define a person, help him or her make decisions, and can even save someone from depression or death. We selected this category because it can show a person's tremendous resilience and strength outside of the cover letter structure. Helping our students analyze and evaluate their own stories could encourage them to transfer these strengths to personal skills that can be added to a cover letter. Moreover, we would like to highlight that the feminist classroom invites us to reflect on and question traditional points of view. We can rethink our hiring processes to open up spaces for people to share their experiences in other ways without judgement or discrimination, thereby, comprehending a greater picture of who they are and what they have accomplished. 


\section{Decision-making}

None of the students identified themselves as decision makers in their cover letters. However, their narratives revealed that they were quick to take risks and make decisions that led to successful outcomes. In the previous category, we saw how Mik took a risk by going to a new church, and CM Barbosa made the decision to turn to her faith. In the next excerpt, Cami, a modern languages student, had the opportunity of a lifetime to see her favorite rock band. Yet, she wrote that all of the tickets were being sold like 'hot bread'. She made the following decision:

Immediately, I contacted with two friends who also wanted to buy the ticket. We all did the process together, and we bought them. It was a dose of medicine for my anxiety. [sic] (Cami)

Here, we can see how Cami sprang into action and called two of her friends. Together, they were able to find tickets to the concert. In addition to Cami's quick decision-making skills, she also expressed how she planned for the concert day. She wrote:

I ascertained the way I had to arrive up there, all the costs that I would have, and the date of that longed day. Even, I thought about clothing that I would wear. What should my hairstyle be like? What things should I carry with me? [sic] (Cami)

In the excerpt above, Cami thought of every detail from the price of going to the concert to what she would wear that day. Similarly, Srta. Conni, a biology undergraduate, described a field trip as a moment that impacted her. In explaining her itinerary during the trip, Srta. Conni mentioned the following:

When we arrived, the first thing was to locate and install the tents and go to dinner at a neighbor's house near the farm where we were. At dusk, we returned to our camp. There was a meeting with the committees to coordinate the instructions for the next day... We always got up very early to finish everything planned. The distances to travel were always long, and we returned in the afternoon, almost night fall. We were all tired and exhausted from work. [sic] (Srta. Conni)

From Srta. Conni's narrative, we interpreted her actions as belonging to a responsible person. For example, she helped with setting up the tents. She was respectful of the instructions given by the committees. Also, she talked about how she got up early every day and completed all the necessary work. Even though Srta. Conni's decisions were not as spontaneous as Cami's, we see that they were necessary to ensure that her field trip would go smoothly.

Cami directly translated a common Spanish phrase, vendido como pan caliente [sold like hot bread], which is equivalent to the American English expression "sold like hotcakes". In other words, the participant wants to highlight that the tickets were gone quickly, which is why they were sold out when she went to buy them. 
Ana Olga Rallón,

Anna Carolina Peñaloza-Rallón

The following excerpt came from Johana's narrative. Johanna, a modern languages student, wrote about the moment she got into college. She began by stating the following:

It was time to choose what I am going to be in the future. How I can help society, also Colombia, be a better place. Where people do not follow just characters which are imposed on tv. [sic] (Johana)

Johanna's story began right before she made the decision of what career path to choose. One thing we noticed from her excerpt was that she wanted to make a difference in the world. For her, a better country was equivalent to having people who did not follow established norms. Based on her narrative, we could interpret that Johana is in favor of critical thinking. As she continued her story, Johana recalled her mother's experience in college. Johanna wrote that:

There, she matured, she got new experiences, she met new friends, also her husband. I remember how she told me that story with great cheer. That was awesome, she could feel freedom after living with my grandparents which were a little traditional with their costumes. But she chooses her freedom instead of traditions. She chooses her future. [sic] (Johana)

We chose to close this category with the excerpt above. Johana told us about her mother's experience in college, which ultimately influenced her decision to apply to the same university. Johana pointed out that her mother made many choices as a student. She was able to pick her friends and partner. Johana made an association between choice and freedom. Later on, we understood that this freedom came from her mother's decision to break away from her family's tradition.

In the category of decision making, we found other skills as organization, problem solving, and responsibility. However, Johana's final excerpt resonates a truth among all of the narratives presented. We understood that women's choice to decide and act are part of their freedom from traditional roles. Whether it is questioning her previous beliefs about God, choosing a career, or preparing for a concert, a woman lives her most extraordinary experiences in the choices she makes.

\section{Conclusions and Pedagogical Implications}

As a second part to this study, we chose to share the results with the participants and ask them how they felt writing their narratives. Johana shared that:

I felt more comfortable. I felt like I could express my feelings or write more. It's not as complex, but I can lay out all of me and write many things ${ }^{10}$. (Johana, Interview)

\footnotetext{
10 Authors' translation.
} 
In addition, we noticed that the female participants were more open to sharing their voice during the rest of the course. This included making us part of their lives and achievements.

Since the course ended, Mik told us she got a raise. CM Barbosa published her narrative in an EFL journal and now she is writing a book. Cami published an article with us and presented her findings at a national conference. Johana is ready to start working on her master's and looking forward to studying gender and power relationships in the classroom. Finally, Srta. Conni is soon to graduate. Her friend, Maratus, who also took the course, became the first person in Colombia to identify the presence of a new spider species in the country.

For this pedagogical proposal, we set out to answer the question: What do women's narratives reveal about their personal skills otherwise silenced in their cover letters? Our study began by implementing narratives as an alternative to uncover the participants' personal skills since they failed to expound upon this section in their original cover letters. In the narratives, we found many skills that could be transferred to a cover letter, while other skills surprised us due to the openness the narrative provided.

One of the skills was spirituality as a source of strength. Spirituality and faith are rarely discussed in cover letters, résumés, or job interviews so that discrimination and religious oppression are avoided. However, spirituality and faith are aspects that define a person's well-being, decisions, and life experiences. Furthermore, a spiritual experience can uncover strengths as resilience, courage, loyalty, and open-mindedness, which could be transferred as personal skills in a cover letter. In this study, the two English language teachers chose to write about their spirituality. CM Barbosa's account described her battle with depression and how she turned to her faith for solutions. From her story, we saw a woman who was loyal, determined, and resilient. Though much of her struggle with depression was lived alone, she found comfort in God and, ultimately, challenged death. Mik's story revealed skills like flexibility, respectfulness, and ability to find commonalities. None of these skills were mentioned in Mik's cover letter. Nevertheless, her experience showed how she was open to trying new things and comprehending others.

We also identified decision-making as a skill shared by all of the narrators. In all of the stories, the women had to make crucial choices at one point. Decision-making was also accompanied by other skills, such as organization, problem solving, and responsibility. Finally, we saw that a woman's choice to make decisions in her life were part of her voice, freedom, and power.

We highlight that the goal of feminist pedagogy is to empower, build community, and open spaces for other voices. We stress that the results obtained would not have been possible without the presence of feminist pedagogy and a complete transformation of the classroom. 
Ana Olga Rallón,

Anna Carolina Peñaloza-Rallón

Throughout the process and in the narratives, we noticed a push against traditional structures seen in academic writing. The women opened up about their spirituality and mental health, which would otherwise be omitted in a cover letter. They also talked about themselves through enriching experiences, which helped us get to know our participants better. By pairing academic writing with narratives, we also see an opportunity to motivate students to take risks in their writing and find their authorial voice. For example, narratives encourage the use of first-person pronouns, which place the author as a subject in her own story. In academic writing, the use of the first-person is still debated since "a student who is not yet positioned as a contributor to the disciplinary discourse cannot refer to himself or herself in the same way that a publishing scholar can" (Nelson \& Castelló, 2012, p. 13). By engaging in storytelling in the feminist classroom, our students are using their voice to question, rethink, and innovate the preexisting structures in place. Therefore, we encourage educators and researchers to find ways to empower their students, amplify women's voices, and challenge colonized academic practices. By doing so, we might be able to contribute to closing the gender gap.

\section{References}

Anzoategui, A. P. (2016). Análisis del modelo pedagógico y el diseño curricular de la escuela de contaduría pública de la UPTC Tunja Boyacá [Unpublished undergraduate monograph]. Universidad Pedagógica y Tecnológica de Colombia.

Badura, K. L., Grijalva, E., Newman, D. A., Yan, T. T., \& Jeon, G. (2018). Gender and leadership emergence: A meta-analysis and explanatory model. Personnel Psychology, 1-33. https://doi. org/10.1111/peps.12266

Bauer, M. (2000). Implementing a liberatory feminist pedagogy: bell hooks' strategies for transforming the classroom. MELUS, 25(3, 4), 265-274. https://doi.org/10.2307/468246

Butler, J. (1990). Gender trouble. Routledge.

Castañeda-Peña, H. (2010). 'The next teacher is going to be...Tereza Rico': Exploring gender positioning in an all-girls school preschool classroom. Magis. Revista Internacional de Investigación en Educación, 3(5), 107-124. https://doi.org/10.11144/Javeriana.m3-5.tnti

Castellanos, J. (2008). Journal writing and its benefits in an upper intermediate EFL class. Profile Issues in Teachers' Professional Development, 9, 111-128.

Coates, J. (1998). 'Thank God I'm a woman': The construction of different femininities. In D.

Cameron (Ed.), The feminist critique of language: A reader (pp. 295-320). Routledge.

de Beauvoir, S. (1949). Le deuxième sexe. Éditions Gallimard.

de Pádua Carrieri, A., Diniz, A. P. R., de Souza, E. M., \& Menezes, R.S.S. (2013). Gender and work: Representations of femininities and masculinities in the view of women Brazilian executives. Brazilian Administration Review, 10(3), 281-303. https://doi.org/10.1590/S180776922013005000002 
Eagly, A. H., \& Karau, S. J. (1991). Gender and the emergence of leaders: A meta-analyses. Journal of Personality and Social Psychology, 60(5), 685-710. https://doi.org/10.1037/0022-3514.60.5.685

El Tiempo. (2018). \#Degeneradas: ¿callan a las mujeres en el Congreso? https://www.eltiempo.com/ elecciones-colombia-2018/congreso/cuantas-mujeres-quedaron-elegidas-para-el-congreso-2018-194604

Fine, I., \& Shen, A. (2018). Perish not publish? New study quantifies the lack of female authors in scientific journals. The Conversation. https:/ theconversation.com/perish-not-publish-newstudy-quantifies-the-lack-of-female-authors-in-scientific-journals-92999

Franco-Orozco, C., \& Franco-Orozco, B. (2018). Women in academia and research: An overview of the challenges toward gender equality in Colombia and how to move forward. Frontiers in Astronomy and Space Sciences, 5, 1-24. https://doi.org/10.3389/fspas.2018.00024

Glaser, B. G., \& Strauss, A. L. (1967). The discovery of grounded theory strategies for qualitative research. Aldine Transaction.

hooks, b. (1989). Talking back: Thinking feminist, thinking black. South End Press.

hooks, b. (1994). Teaching to transgress: Education as the practice of freedom. Routledge.

Langellier, K. M. (2001). Personal narrative. In M. Jolly (Ed.), Encyclopedia of life writing:

Autobiographical and biographical forms (pp. 699-701). Fitzroy Dearborn.

Mauranen, A., Pérez-Llantada, C., \& Swales, J. M. (2010). Academic Englishes: A standardized knowledge? In A. Kirkpatrick (Ed.), The Routledge handbook of world Englishes (pp. 634-652). Routledge.

McClusker, G. (2017). A feminist teacher's account of her attempt to achieve the goals of feminist pedagogy. Gender and Education, 29(4), 445-460. https://doi.org/10.1080/09540253.2017.12 90220

Minciencias. (2018). Mujeres ciencia. http://www.todoesciencia.gov.co/mujeres-ciencia

Nelson, N., \& Castelló, M. (2012). Academic writing and authorial voice. Studies in Writing, 24, 1-30. https://doi.org/10.1108/S1572-6304(2012)0000024007

Olaya, A., \& Gómez, L. F. (2013). Exploring EFL pre-service teachers' experience with cultural content and intercultural communicative competence at three Colombian universities. Profile Issues in Teachers' Professional Development, 15(2), 49-67. https:/ / revistas.unal.edu.co/index.php/ profile/article/view/40168

Osborn, T. A. (2007). Social justice, the spirit of the people, and language education. In D. I. Smith \& T. A. Osborn (Eds.), Spirituality, social justice, and language learning (pp. 3-12). Information Age Publishing.

Pavlova, M. K., \& Silbereisen, R. K. (2015). Leisure activities choices among adolescents. In J. Wright (Ed.), International encyclopedia of the social \& behavioral sciences (pp. 830-837). Elsevier.

Peñaloza, A. C. (2019). Gender positioning in academic writing [Unpublished master's dissertation]. Universidad Pedagógica y Tecnológica de Colombia. 
Ana Olga Rallón,

Anna Carolina Peñaloza-Rallón

Plummer,M., \& Young,L. (2010). Grounded theory and feministinquiry: Revitalizinglinks to the past. Western Journal of Nursing Research, 32, 305-321. https://doi.org/10.1177/0193945909351298

Purdue Online Writing Lab. (n.d.). What is a cover letter? https://owl.purdue.edu/owl/job_search_ writing/job_search_letters/cover_letters_1_quick_tips/index.html

Ramos, B., \& Aguirre, J. (2014). Materials development in the Colombian context: Some considerations about its benefits and challenges. HOW Journal, 21(2), 134-150. https://doi. org/10.19183/how.21.2.8

Rappaport, J. (1995). Empowerment meets narrative: Listening to stories and creating settings. American Journal of Community Psychology, 23(5), 795-807. https://doi.org/10.1007/ BF02506992

Ropers-Huilman, B. (1999). Scholarship on the other side: Power and caring in feminist education. NWS A Journal, 11(1), 118-135.

Shackelford, J. (1992). Feminist pedagogy: A means for binging critical thinking and creativity to economics classroom. Alternative Pedagogies and Economic Education, 82(2), 570-576.

Shrewsbury, C. (1987). What is feminist pedagogy? Women's Studies Quarterly, 15(3, 4), 6-14. https:// www.jstor.org/stable/40022001

Teleky, R. (2001). "Entering the Silence": Voice, ethnicity, and the pedagogy of creative writing. MELUS: Multi-Ethnic Literature of the United States, 26(1), 205-219. https://doi. org/10.2307/3185503

Tong, R. (2001). Feminist theory. In N. J. Smelser \& P. B. Baltes (Eds.), International encyclopedia of the social and behavioral sciences (pp. 5484-5491). Elsevier.

UNESCO. (2016). Colombia: Human resources in R\&D. http://uis.unesco.org/en/country/ co? theme $=$ science-technology-and-innovation

Webb, L. M., Allen, M. A., \& Walker, K. L. (2002). Feminist pedagogy: Identifying basic principles. Academic Exchange Quarterly, 6, 67-72.

World Health Organization. (2018). Gender. http://www.who.int/gender-equity-rights/understanding/gender-definition/en/ 